\title{
LINGUISTIC SCIENCE AND LANGUAGE TESTS
}

\author{
ROBERT LADO \\ University of Michigan
}

\section{Introduction}

Do recent advances in linguistic science have any bearing on language tests? They do. But linguists like other scientists have a jargon all their own and their findings are not easily interpreted. I explored the use of linguistic techniques and findings in tests in English as a foreign language, 1 and found such promising results that a new movement in foreign language tests seems possible and worthwhile through a better understanding of linguistic science in that field. This article is only an introduction of course. It gives just enough of a view of what we mean by linguistic science to show how it can be used and what kind of a contribution it can make to language tests.

\section{Common Sense and Language Tests}

Before we can use linguistic science, in fact, before we can even see the need for it in tests, we must, to avoid some common pitfalls, use what we might as well call common sense. Because we do so much through language we often find it difficult to see clearly just where language ends and where the things we do through it begin. Because we always use language in certain situations, we sometimes think of the situation itself as the essence of language, This hazy view of language is often at the root of much of the confusion in language tests. Let me illustrate.

Although one has to know English, for example, to understand a lecture in a university classroom in the United States, knowing English does not mean that one can understand the lecture. Only recently I sat for an hour in a class in advanced

\footnotetext{
${ }^{1}$ Measurement in English as a Foreign Language (Ann Arbor, University Microfilms, 1950), University of Michigan dissertation.
} 
calculus and I could not understand the teacher's explanation. I understood most of his words, his pronunciation was familiar, and the grammatical signals that he used were clear, but I did not understand what he was talking about. In other words, I understood his "language" but I did not understand his subject matter. This, you will grant, illustrates validly a general fact: that no one, not even the college graduate himself can be expected to understand the subject matter presented in any and all university classes. The subject matter then must be kept within the experience of the student if what we are interested in is testing his control of the foreign language.

The situations in which language can be used range all the way from simple greetings to abstract metaphysical speculation. They encompass the full breadth of man's thought, activity and emotion. Certainly there is no one who can speak intelligently in all of them. To work on language tests on the single assumption that the problem is to determine the situations in which a student can speak intelligently does not seem a very promising approach. Yet this "situation" approach lures many, especially in English as a foreign language, as if it were the ultimate and unquestionable solution.

Another matter that is clearly not the purpose of a foreign language test is the attempt to determine if the examinee is or is not a good student. It is true that people dealing with the admission of foreign students in the United States need to know what kind of a student the applicant is. But a test in English as a foreign language is a poor way to find that out. A better way is to find out what kind of a student he has been in the past, and his academic records are as good an indication of that as any. The test in English will tell only how well he can use the language so that, provided he is a good student, he will be able to make good in an English speaking school.

The student's mental ability-his I.Q. - is not the business of a language test either. The only concession we need to make in the matter of I.Q. is a negative one-to keep it from being a decisive force in any item. Language is something that people with average intelligence can use. If the students fail an item because only those with a high I.Q. can manage it, we should not consider it valid in a foreign language test. 


\section{LINGUISTIC SCIENCE AND LANGUAGE TESTS}

And since I am talking about the things that do not concern us in foreign language tests I will also exclude literary skill. Literary skill requires special talent and training. A foreign speaker may or may not possess them in his native language, which we assume he knows. All we hope to find out in a foreign language test is how well he has mastered the significant elements of the system of signals that constitutes that foreign language. Beyond that the problem is one that concerns teachers of literary writing.

A rule of thumb that will help define a foreign language from the point of view of tests can be put negatively thus: a foreign language is something that does not baffle native speakers of that language. Or to put it affirmatively, a standard foreign language is something that educated native speakers of that language know by the mere fact of being native speakers of it. If some language problem baffles educated native speakers it is possibly a matter for tests in that language as a native language but not as a foreign language.

In An Investigation of Second-Language Teaching which has a chapter on English as a foreign language it is claimed that the performance of native speakers could not be used as a criterion because they did not take the tests seriously.

In grammar tests, for example, the American student is accustomed to being harassed with problems like "The man (who? whom?) I think will be elected is popular" and "The number of possible answers (is? are?) small." He is used to puzzling over these problems and disgracing himself by his choices. But confronted by "I arrived there (on? at? in?) Saturday," he thinks that the instructor is crazy or is pulling his leg. 2

My experience with such tests has been altogether different, however. I gave grammar tests of that kind to English speaking graduate students, and they took them seriously enough to make perfect or nearly perfect scores. I also used a test of perception which asks if beat and bit for example are the same word or two different ones. And thirty-three seniors and

\footnotetext{
${ }^{2}$ F. B. Agard and H. B. Dunkel, An Investigation of Second-Language Teaching (Boston, Ginn and Company, 1948), Chapter VII, p. 261.
} 


\section{ROBERT LADO}

graduate students who took it showed keen interest throughout and made very high scores of course. Furthermore, some well known experiments in psychology were based on exceedingly simple tasks. Thorndike, for example, reports no trouble with lack of interest in an experiment which he describes as follows:

Consider, for example, the following experiment: You sit at your desk with a large pad of paper and a pencil, close your eyes, say, "Draw a four-inch line with one quick movement," and again and again draw with one quick shove a line intended to be four inches long. You keep your eyes closed throughout. Day after day you do this until you have drawn 3,000 lines, no one of which you have ever seen. 3

If the students know that they are taking part in an experiment -trying out a test for foreign students in our case-they will more than likely show the necessary interest to justify that kind of check on the test.

Trying the tests on native speakers of a language will show some of the things that should be left out of the tests, but it does not tell us what we should put into them. We of course agree that it should be language. But up to a relatively few years ago that was about all you could really do. You could take something you thought was language, put it into the form of a test, and submit it to the usual statistical treatment. Today we can do very much better.

\section{Linguistic Science and Language Tests}

The situations in which language can be used are infinite, and it is easy indeed to find a situation in which any given speaker cannot express himself. Linguistic science shows, however, that the meaningful elements of any one language are strictly limited. The significant sounds in any of the known languages does not exceed three or four dozen. The meaningful structures are also limited in number, and the words themselves can be exhausted in any language. This is then where

\footnotetext{
${ }^{3}$ E. L. Thorndike, Human Learning (New York, The Century Co., 1931), p. 8 .
} 
linguistic science makes its contribution to the problem of testing. It changes the problem from one of determining what situations of an infinite number can be handled by a person to one in which we try to measure the student's control of a definitely limited number of signals and symbols operating in a language system. Some developments in lirguistic science are particularly relevant to us here.

Henry Sweet (1845-1912) spent time and effort writing down all the minute differences in sound he could hear. He even developed a system of symbols, Romic, to record those sounds. But he ran into trouble. The more carefully he listened, the greater the number of minute differences he could hear and the more complicated became his system of symbols and diacritic marks. As a matter of fact, laboratory instruments later showed that no two speech sounds are ever exactly alike except by a rare coincidence. Sweet did not have to wait for those laboratory instruments, however. He noticed that he could operate rather well without recording all the variations he had trained himself to hear. So he simplified his notation and called it Broad Romic. He was not clear what he could base his decisions on, and he was never happy about this broad notation, but we know now that he was reacting to a very important linguistic fact, the phonemic principle.

Edward Sapir (1884-1939) observed that "although no two individuals have precisely the same pronunciation of a language ... they aim to make the same sound discriminations, and the pattern of those discriminations is the same. He noticed that although in English the vowel in bad is longer than the vowel in bat, for example, and that the vowel in bead is also longer than the one in beat, these and many other variations are purely mechanical. $\overline{5}$ As far as the phonetic pattern of English is concerned the vowels in bad and bat belong to the same sound, to the same "point in the pattern" of English. He noticed also that the same or a similar difference might constitute two separate points in the phonetic pattern of another

\footnotetext{
${ }^{4}$ Edward Sapir, "Sound Patterns in Language," Language, Vol. 1, 1925, p. 41.

${ }^{5}$ The vowels are longer before voiced consonants like $b, d, g$ and continuants like $1, \mathrm{~m}$, and shorter before voiceless stops like $\mathrm{p}, \mathrm{t}, \mathrm{k}$.
} 


\section{ROBERT LADO}

language. He concluded that "the sounds used by a language form a self contained system, $" 6$ and that the sounds are meaningless unless they are interpreted in terms of the phonetic pattern of that system. Linguists now call these "points in the pattern" that Sapir was concerned with, phonemes, the "phonetic pattern" is called the phonemic system of that language, and the study of these things, phonemics or phonology.

Sapir saw with clarity the phonemic principle but he expressed it in unworkable terms. Leonard Bloomfield (18871949) later set down workable postulates that made phonemics into a new science. 7 His treatment of phonemics in his book Language is considered a classic. ${ }^{8}$ Another linguist, Kenneth L. Pike, wrote a textbook to train students to apply the phonemic principle in describing the sounds of any language. 9

But what does all this have to do with us? Aren't we interested in tests? We are, but they are language tests. And these findings tell us very definitely what sounds are important in the operation of the language we want to test. This science gives us the facts and the tools to decide what should go into our tests. With those tools we can decide independently what elements in the great variety of sounds found in any language really make a difference in the operation of that language and what elements are merely matters of accent or personal indiosyncracy.

And the exciting thing is that the kind of progress already made in getting at the sounds of a language is even now being realized in the grammar of language. The kind of minute, often meaningless description of the grammar of a language is giving way to the study of things that carry the grammatical signals in a language.

Charles C. Fries would point out for example that in the series of sentences, He goes there, She goes there, John goes

\footnotetext{
${ }^{6}$ Ibid., p. 40.

7"A Set of Postulates for the Science of Language," Language, Vol. 2, 1926, pp. 153-64.

8(New York, Henry Holt and Company, 1933).

${ }^{9}$ Phonemics: A Technique for Reducing Languages to Writing (Ann Arbor, University of Michigan Press, 1947).
} 
there, Who goes there, all spoken with the same falling intonation, the changes in the first three sentences do not alter the kind of sentence it is, but the change to who in the fourth one makes it into a question. Some of the variations in the words and their arrangement do not make any difference grammatically, while others, just as simple, do make a difference. He would also point out that each language has its own system of grammatical signals, and that a grammatical signal is meaningless unless it is interpreted in terms of that system. Thus in English the sentence You are an artist is a statement and Are you an artist, spoken with the same falling intonation, is a question by virtue of the different word order which happens to be significant in the grammatical system of English. In Spanish, however, the same change in word order does not result in a question, and so we have Usted es un artista, a statement, and Es usted un artista, also a statement.

We have considered the sounds and the structure of a language as of importance in language tests. If we add the words-the lexical items-we have the three ingredients that interest us most in such tests. Through linguistic science we can locate and describe the system of significant sounds and the system of structural signals of a language. This knowledge plus an accurate description of the words and how they are used place us in a position to develop a whole new set of tests that can be better than those prepared without the aid of linguistic science. But there is one more thing we can do to make our tests even more to the point.

Since we are dealing with foreign languages we assume that we will test people who already possess a system or systems of linguistic signals in their native language. We can also assume that that system is similar to that of the foreign language in some respects and different in others. By comparing the foreign language with the native language we can not only test those things which are important in the foreign tongue but we can test particularly those things which operate differently from the system of the native language of the student. We now have the secret to get at the heart of language and to waste no time with the things that the student will know if he knows his native language at all. In other words, we now have the tools to discover surely what should go into our tests, and with a minimum of dead wood at that. 
ROBERT LADO

\section{SELECTED REFERENCES}

Bloomfield, Leonard, Language (New York, Henry Holt and Company, 1933).

Fries, Charles C., Teaching and Learning English as a Foreign Language (Ann Arbor, University of Michigan Press, 1945).

Fries, Charles C., The Structure of English (New York, Harcourt, Brace and Company, 1951).

Pike, Kenneth L., Phonemics (Ann Arbor, University of Michigan Press, 1947). 